\title{
General Attitude towards Advertising: Cultural Influence in Pakistan
}

\author{
Muhammad Usman (Corresponding author) \\ Faculty of Management Science, International Islamic University Islamabad, Pakistan \\ Tel: 92-321-569-3668Ｅ-mail: usman2.sattar@gmail.com \\ Saqib Ilyas \\ Faculty of Management Studies, University of Central Punjab, Lahore, Pakistan \\ Tel: 92-333-568-9397_E-mail: ilyas.saqib@gmail.com \\ Muhammad Farooq Hussain, Associate Professor \\ Faculty of Management Studies, University of Central Punjab, Lahore, Pakistan \\ Tel: 92-321-539-7026Ｅ-mail: farooqyhussain@gmail.com \\ Tahir Masood Qureshi, Associate Professor \\ Faculty of Management Studies, University of Central Punjab, Lahore, Pakistan \\ E-mail: tahirmasood2002@gmail.com
}

\begin{abstract}
The objective of this research is to examine cultural influence on the general attitude of Pakistani people towards advertising. The study aims to analyze the cultural impact on attitude of people towards advertisements of brands according to product information, social integration and hedonism/pleasure, whereas power distance and masculinity as culture dimensions. Sample size includes 250 respondents which are involved directly in purchasing. It includes adults from all disciplines, house wives within the vicinity of Islamabad/ Rawalpindi and the people from different age groups and educational backgrounds. Regression is used to check the impact of product information, social integration and hedonism over public general attitude towards advertisement. And apply moderation analysis to check the impact of culture as moderating variable. Social integration, product information and hedonism have a significant impact on attitude towards advertisement. But product information has weak impact on attitude towards advertisement; whereas culture has a significant moderating effect which strengthen the relationship between dependent and independent variables. The most important limitation was the time constraint. The time was limited due to which a huge sample size was impossible to manage. The responses were taken only from Islamabad and Rawalpindi cities which restrict the generalizability of the study. This study will help marketers to advertise there products according to the culture values and attitude of the people which reflects their personality. It will also help companies to segment their customers according to their behavior/attitude towards advertisement, which in turn will help companies to gain competitive advantage and increase profitability.
\end{abstract}

Keywords: Advertising, Attitude, Social integration, Hedonism, Power distance, Masculinity

\section{Introduction}

Advertising as a major social event expresses a key change in values, beliefs, behavior and buying patterns of the peoples which influence the lifestyles of people (Polly and Mittal, 1993). Hoo and Munusamy (2007) cited that Attitude toward advertising is a core concept and basically is one of the determinants of attitude towards any particular advertisement (Lutz, 1985); attitude of the consumer or person towards a single particular advertisement is influenced by attitude towards general advertising (Bauer and Greyser, 1968; Lutz, 1985). Tan and Chia (2007) cited that researchers examines favorable or unfavorable attitude towards advertising (Zanot, 1984; Barnes, 1982). Petrovici and Marinov, (2007) said that Core reasons for the change in the lifestyle and buying pattern of a person are the economic transformation and certain market opportunities (Meth-Cohn, 1999), which result the attitude towards advertising during evaluation of consumers market (Fessel - GFI, 1997). Hoo and Munusamy (2007) cited that much of the research has been done at macro level on a two classical dimensions; social and economic effect of advertising (Bauer and Greyser, 1968), whereas Pollay and Mittal 
(1993) present product information, social role, and hedonism as a personal dimension for attitude towards advertisement at micro level.

This study tends to investigate the cultural influence general attitude and beliefs toward advertising associate with the observation of the customer of advertising affective ness. Sandage and Leckenby (1980) distinguish advertising as instruement and institution. The institution component has been defined as the 'economic and social role that society has given to advertising institutions to implement (Sandage and Leckenby, 1980), 'carrying out qualities and the failures of advertisement is concerned with the advertisement instruement (Sandage and Leckenby, 1980).Advertisement had also been criticized by presenting wrong information about products, violation of social norms and abusing consumer intelligence (Pollay, 1986; Pollay and Mittal, 1993).

Pakistan is considered as an emerging market; due to trends of globalization, establishment of multi-national companies; advertisement has undergone drastic changes in the recent years which has a great impact on the attitudes and beliefs of the consumer. Attitude reflects the broad observation or assessment of some product and idea whereas beliefs are used to measure that assessment of that product on some feature or information (Fishbein and Ajzen, 1975); determinants of advertising i.e., information related to product, social integration, pleasure/amusement (Polly and Mittal, 1993). This paper attempts to find the research problem based on extant literature on consumer attitude towards advertising leading to the development of research framework that defines data collection and sampling frame for improved theoretical and managerial knowledge of marketing and advertising dimension in the market.

\subsection{Objective of Study}

The objective of the research is to examine how the culture affect peoples perceive advertisement and there general attitude towards it by establishing the relationship with product information, social integration and hedonism.

\subsection{Significance of Study}

This study will help both; international and domestic marketers to introduce their products according to the local culture of the country and according attitude/behavior of the people by keeping in mind that how people perceive advertisement and react accordingly. Marketers should exploit the behavior of the consumers towards advertisement, which in return will influence their buying patterns.

\section{Literature Review}

Attitude towards advertising is a tendency to react in continuous favor or unfavorable mode towards advertising in general (Mackenzie and Lutz, 1989). Whereas attitude is define as intellectual way an individual can use to organize they way they see their environment and guide them to respond that environment (Aaker et al., 1986). Rossiter (1977) said that attitude of a person toward advertising is a major sign of getting brand awareness and attitude towards brand. Hoo and Munusamy (2007) said that a positive correlation between favorable attitude and consumer's evaluation to a specific advertisement is observed as irritating, pleasant and likeable (Bauer and Greyer, 1968). Researchers propose that attitude or a behavior of an individual is interlinked with each other which result in change and advance their buying behavior. This behavior can be positive or negative (Hawkins, Best and Coney, 1976; Antonides and Raaji, 1998; Zanot, 1984).

It has been found in prior literature that attitude of a consumer towards advertising increasingly negative. Most of the researcher yield positive result too (Calfee and Ringold, 1988; Pollay and Mittal, 1993; Rotzoll, Haefner and Sandage, 1986; Ryans, 1982). As found by the Gallup organization in early survey of consumer attitude towards advertising that lot of peoples likes advertisement and found it informative and some of the studies only focused on the attitude structure. Elliot and Speck (1998) investigate six major media of advertisement which includes TV, broadcasting, magazines newspaper, yellow pages and direct mail. In this research researcher focused on the advertisement communicated in TV. Hoo and Munusamy (2007) said that there was a basic difference stated by Lutz (1985); Sandage and Leckenby (1980) between the intuitions and instrument of advertising. Institution means the function and effect where as instrument are the process and the practices towards general attitude (Sandage and Leckenby, 1980). Hoo and Munusamy (2007) cited that Social and economic effects are related to institution dimensions of the advertising (Bauer and Greyser, 1968). Instrument Dimension is the executional qualities of advertising have long been the focus of study exploring the advertising effectiveness and attitudes held towards advertising. These executional qualities have been measured, such as informational value of advertising (Haller, 1974; Durand \& Lambert, 1985), poor taste and sex in advertising (Larkin, 1977) and the need of the government regulation in advertising (Durand \& Lambert, 1985). The primary 
determinants which portray the personal beliefs about benefit the customer get from viewing advertising such as being entertained, providing social image or providing information (Polly and Mittal, 1993).

Norvis (1984) found that importance of advertising as an information provider leads to greater market place and a positive image in market as consumer are better able to match their needs and wants against the product offering. Product information provided through advertisement plays a vital role in changing the behavior or attitude of the consumer towards advertising (Polly and Mittal, 1993) and also the purchasing behavior by meeting their needs after getting information about that product or services; advertised in TV (O'Donohoe, 1995). Product information is a basic personal belief factor which moulds the belief of customers about the informative character of the advertising. Different peoples have different expectation about advertisement in different media, for example some peoples like to have information from the print advertising rather then TV advertising (Speck and Elliott, 1997).

Advertising gives support in the development of consumers self image (Richins, 1991) and product meaning (Friedman and Zimmer, 1988), with many consumers paying valuable dollars for branded clothing which featuring prominent logos, slogans and other corporate design (Polly and Mittal, 1993). Advertising helps consumer in developing their own identity and style, which in turn will create positive image of advertising but According to Mittal (1994) consumer generally do not believe advertising reflects their image.

Advertising gives support in the development of consumers self image (Richins, 1991) and product meaning (Friedman and Zimmer, 1988), with many consumers paying valuable dollars for branded clothing which featuring prominent logos, slogans and other corporate design (Polly and Mittal, 1993). Advertising helps consumer in developing their own identity and style, which in turn will create positive image of advertising but According to Mittal (1994) consumer generally do not believe advertising reflects their image. Advertisement can serve as a source of entertainment or pleasure (Alwitt and Prabhaken, 1992; Polly and Mittal, 1993). The more the pleasure and entertainment in advertising the more it will be liked by the consumer, with research showing that the hedonic function is significant in influencing favorable attitude towards advertising (Alwitt and Prabhakar, 1992; Mittal, 1994).

Each individual have a unique set of values, there are also some particular values that focus on a culture, these values are distinguished from personal values because they lead to the foundation on which culture rests (McCarty, 1994). Culture values can be transferred by a variety of useful resources (family, media, school, church, and state (Samovar et al., 1998). The role of advertising has long been debated, if the variation in advertising contents is independent of a culture values the purpose of an advertisers facing peoples in multivariate culture will be challenging. Role of culture in advertising is particularly important in transferring advertising strategy across the world, because communication patterns are closely linked to culture values and norm in each particular country (Hong et al., 1987). Now a day Asian markets are growing quickly and efficiently throughout the world (Shao et al., 1999). Asia is also having the major growth market for multinational companies. In this regard strategies of advertising in Asia is getting popular under the assumptions of rising living standards of peoples and growing similarities of consumer In particular region (Tai, 1997). Some of the critics have also been claimed that consumer's response favorably to advertising and reward a particular advertisement with purchases if advertising message are similar with the core culture values of that country (Zhang and Gelb, 1996 Belk et al.1985) advertisements that reflect some local cultural values are more persuasive than those that ignore them (Gregory and Munch, 1997).

Figure 1 here: Primary Determinants on Advertising towards general attitude

Based on existing literature about attitudes towards advertising and consumer behavior models, a research framework have been constructed which show the relationship among product information, social image and hedonism/pleasure. The above figure shows the relationship between three construct and general attitude towards advertising graphically. Three sets of hypothesis are developed from the above framework as guided by Polly \& Mittal (1993).

$\mathrm{Ho}_{1}$ : Product information does have positive effect on general attitudes towards advertising.

$\mathrm{Ho}_{2}$ : Social integration/image does have a positive effect on general attitudes towards advertising.

$\mathrm{Ho}_{3}$ : Hedonism/ pleasure do have a positive effect on general attitudes towards advertising.

The study focused on primary determinants of general attitude towards advertising adopted by (Petrovici and Marinov, 2007) from the Polly and Mittal (1993) model of attitude towards advertising. In advertising and international marketing, understanding of a country's core cultural values is very important and these values have a powerful; influence on country's characteristics and consumer behavior (Watson et al., 2002).). Research 
efforts were made to develop universal values that characterize and distinguish cultures (Kluckhohn and Strodtbeck, 1961; Rokeach, 1973; Hofstede, 1980, 1991; Schwartz, 1992) and among those, Hofstede's (1980) cultural dimensions provided the first empirically and conceptually based set of value dimensions to compare cultures (Watson et al.2002). In this study researcher took two dimensions of culture i.e., power distance which indicates the degree to which the power difference are accepted and allowed by society. Hofstede (1980) explained that the power distance index explains how diverse societies address basic human inequalities in social status and prestige, wealth and source of power. The societal norms in a country obtaining high score on the power distance index dimension are for powerful people to look as powerful as possible. People with power are considered to be right and good. Powerful people are expected to have privileges. In countries with large power distance, the exercise of power gives satisfaction and powerful people try to maintain and increase power differences (Hofstede 1980). The masculinity dimension indicates the degree to which common male values are important to a society (Hofstede 1980). The societal norm in a particular country with high score on the masculinity dimension is to have an achievement ideal, to value productivity and try to be best among all big and fast are considered beautiful (Hofstede 1980).

$\mathrm{Ho}_{4}$ : Culture moderate the relationship between hedonism, product information, social integration and attitude towards advertising.

\section{Methodology}

\subsection{Sample}

A questionnaire survey was conducted to gain insight of the consumers' behavior towards advertisement and the factors which contribute in changing consumers' attitude. Questionnaires were developed for the surveys which were distributed in different universities and house holds. To obtain the relevant information, population surveyed consisted of students, house wives and people from all walks of life. A total of 300 questionnaires were administered to potential respondents chosen from various areas of Rawalpindi and Islamabad. A total of 250 usable questionnaires were returned, giving a response rate of $87 \%$. Demographics were also included in order to control their effect while measuring consumers' attitudes towards advertising.

3.1.1 Age: Shavitt, Lourey and Haefner (1998) found that younger consumers show more favourable attitude towards traditional advertising in a number of dimensions than older so people there is a significance impact of advertisement towards general attitude.

3.1.2 Gender: The research conducted by Ozhan (2004) highlights that advertisement could be done by using mobile as a media, women and men perceived mobile phones differently. The researcher has different affect on advertisement which has a different impact on their attitudes and beliefs.

3.1.3 Education: The last demographic dimension used for the collection of data is education of the consumer. Patrovici \& Marinov (2007) reported that as the level of education increases, the level of negative attitude towards advertising increases whereas Shavitt, Lowery and Haefner (1998) found that person having less education have more positive response towards advertising through mobile medium. From their finding the researchers found different impact of attitudes between high educated people and people with less education.

\subsection{Measures used for questionnaire}

The questionnaire was designed to measure general attitude of consumers towards advertising. Likert scale was used for dependent variable attitude towards advertising, independent variables (product information, social integration and hedonism/pleasure) and moderating variable culture ranging from 1 to 6 where 1 is coded as "strongly agree" to 5 is coded as "strongly disagree".

3.2.1 General attitude towards advertising: construct is measured on 8 items that are exaggeration in advertising; advertising resulting in lower prices, increase in the cost of goods and services, persuasion of people to buy products they don't need, influencing people in choice of life goal, desire of being independent, and influencing people's lifestyle in our society.

3.2.2 Product information: is measured on 7 items that are advertising is a valuable source of information about local sales / product learning of brands which consumer is looking for, knowledge about quality product, availability of the product (Patrovici \& Marinov, 2007).

3.2.3 Social integration: is measured by 4 items that are role of advertising in children education, learning of fashion, talking about advertisement to family and friends, presenting consumers who find advertisement status oriented (Patrovici \& Marinov, 2007). 
3.2.4 Hedonism / pleasure: construct have been measured by 3 items that are advertising is often amusing and entertaining, getting pleasure from the advertising, it brings pleasant memories. (Patrovici \& Marinov, 2007).

3.2.5 Culture: Constructs of culture have been measured by 8 items that are Advertisements reflect our cultural values; high quality products with higher prices have a positive buying attitude towards upper class, Society has negative attitude towards advertisements with female discrimination content, Males have a negative attitude towards advertisement, if females are advertising in male related products, Females have a negative attitude towards advertisement, if males are advertising in female related products, An advertisement which doesn't represent lower class create negative attitude in that class.

\subsection{Procedure}

Data was collected through primary sources. Structured questionnaire was used for data collection which was taken from Polly and Mittal (1993) studies and was modified according to Pakistani environment. Data was cross sectional which has been collected once through preliminary data gathering. Questionnaires were filled by students, adults, house wives and people from various disciplines. Convenient sampling which is also called nonprobability sampling has been used due to restricted time frame. By taking convenient sampling it was easy to choose from accessible subjects.

SPSS 14 has been used for data analysis. Study falls under measure of association to check colinearity of variables. Multiple regression tools have been used to check the significance level of independent variables on dependent variable. The chi-square test has also been applied for checking the overall significance level.

\section{Results}

To study the attitude of consumers towards advertising, a one-way analysis of variance, ANOVA, was performed to examine the overall significance of model. The analysis enables to examine the individual impact of the independent variables on the level of consumers' attitude towards advertising. Table1 shows direct effects of all independent variables which includes hedonism, product information and social integration has significant impact (0.00) on attitude towards advertising. So overall the model is significant.

To test hypothesis $\mathrm{Ho}_{1}, \mathrm{Ho}_{2}, \mathrm{Ho}_{3}$ regression analysis has been used. Table 2, 3 and 4 shows that product information has $(\boldsymbol{\beta}=.131, \mathrm{p}<0.05)$, social integration $(\boldsymbol{\beta}=0.513, \mathrm{p}<0.05)$, hedonism $(\boldsymbol{\beta}=.224, \mathrm{p}<0.05)$ has significant impact on consumers attitude towards advertising, in next step moderation analysis has been used to test $\mathrm{H}_{04}$. Table 5, 6 and 7 shows that culture plays a significant moderating role to enhance the impact of hedonism, product information and social integration over general attitude towards advertising. Only with product information culture has a weak moderating impact $(\boldsymbol{B}=.231, \mathrm{p}<0.04)$. Culture has strong moderating role with hedonism ( $\mathbf{\beta}=.365, \mathrm{p}<0.00)$ and social integration $(\boldsymbol{\beta}=.461, \mathrm{p}<0.00)$, confirming that hypothesis $\mathrm{Ho}_{1}, \mathrm{Ho}_{2}$, $\mathrm{Ho}_{3}$ and $\mathrm{H}_{04}$ has been accepted. In these cases null hypothesis is been rejected and alternative hypothesis is been accepted.

Table 8 shows correlations of variables. It shows that product information has a correlation with attitude towards advertisement at the significance level of 0.05 , so both variables don't show strong correlation. Social integration shows strong correlation with attitude towards advertising at the significance level of 0.01 but social integration and product information has a weak correlation at the significance level of 0.05 . Hedonism/pleasure has a strong correlation with attitude towards advertising at the significance level 0.01. Product information and hedonism/pleasure does not show any correlation in between them. Social integration and hedonism/pleasure shows strong correlation at the significant level of 0.01 .

Culture has a weak correlation with product information at a significant level of 0.02 on the other hand culture showing negative correlation with hedonism and social integration. All the constructs are correlated except product information and hedonism, culture with hedonism and social integration which does not show any correlation with each other.

\section{Table 1-8 here}

\section{Discussion}

The findings reveal that advertising tell consumers which brands and services they are looking for. Advertising contributes to consumers' knowledge about quality products which in turn lead to positive attitude towards advertisement. Consumers have positive attitude towards advertisement if they bring pleasant memories in consumers mind. Exciting advertisements attract their customers and create positive buying attitude towards the advertised product. Consumers have positive attitude towards those advertisements which play an important role in children's education. Results show that product information has a weak impact on attitude towards 
advertisement so it means that advertisements are not conveying complete information about the product to consumers. Marketers have to keep in mind while making advertisements that it conveys the complete information about product. Culture plays very important role while making advertisements. It plays a strong moderating role between impact of hedonism and social integration over attitude towards advertising. On the other hand culture has a weak moderating role towards the impact of product information on advertising.

\section{Conclusion}

This study illuminated two aspects; the first one is that youngsters in the society are influenced by the advertising and advertising results the higher prices of the product the life style of the people are slightly affected by it due to the economic circumstances. An important aspect of the study is that culture has a strong influence as a moderator over hedonism and social integration impact on general attitude towards advertising.

Pakistan is undergoing many changes due to globalization, exposure to reflected in the current advertising affects the younger people in our society whereas lots of people think that advertising is merely an exaggeration of the product. Almost most of the people are aware of the informational and hedonic role of advertising but also it influences the children and now a day's people are following the new trends and fashion for their image building. The perception of people about effects of new advertising trends according to our cultures in our society should be studied by the companies before making any kind of advertisements because if people or customers are not satisfied then businesses can not flourish.

The trend of globalization, internet and some other causes are already adversely affecting the culture and traditions of our society and if we didn't revise our advertisements then it can worsen the moral and ethical values of our society therefore it is strongly recommended that advertising agencies, marketers and all the companies themselves should make sure that the marketing campaigns do include all the social- groups and people and are also in consistent with our traditions, social norms and values.

\section{References}

Aaker, D. A., Douglas, M., Stayman, \& Michael, R. H. (1986). Warmth in advertising: Measurement, impact and sequence effects. Journal of Consumer Research, 12 (3), 365-81.

Alwitt, L.F., \& Prabhaker, P.R. (1992). Functional and belief dimensions of attitudes to television. Journal of Advertising Research, 32(5), 30-42.

Antonides, Gerrit, \& Fred V. R. (1998). Consumer behavior: A European perspective. New York: Wiley and Sons.

Barnes, M. (1982). Public attitudes to advertising. Journal of Advertising, 1(2), 119-28.

Bauer, R.A., \& Greysen, S.A. (1968). Advertising in America: The consumer view. Boston: Harvard University.

Belk, R.W., Bryce, W.J., \& Pollay, R.W. (1985). Advertising themes and cultural values: a comparison of US and Japanese advertising. in Mun, K.C. and Chan, T.C. (Eds), Proceedings of the Inaugural Meeting of the Southeast Region, Academy of International Business, Hong Kong, 11-20.

Calfe, J.E., \& Ringold, D.J. (1994). The 70\% majority: Enduring consumer beliefs about advertising. Journal of Public Policy and Marketing, 13(2), 228-38.

Durand, R., \& Lambert, Z. (1985). Alienation and criticism of advertising. Journal of Advertising, 14 (3), 9 - 15

Elliot, M.T., \& Speck, P.S. (1998). Consumer perception of advertising clutter and its impact across various media. Journal of Advertising Research, 38 (1), 29-41.

Fessel, G.F.K. (1997). Socio-styles, unpublished report. Fessel - Gfk Ltd: Vienna.

Fishbein, M., \& Ajzen, A. (1975). Attitude, intention and behavior: An introduction to theory and research. Reading, MA: Addisson - Wesley.

Friedman, R., \& Zimmer, M. (1988). The role of psychological meaning in advertising. Journal of Advertising, $17(1), 41-48$.

Gregory, G.D., \& Munch, J.M. (1997).Cultural values in international advertising: an examination of familial norms and roles in Mexico. Psychology \& Marketing, 14(2), 99-119.

Haller, T. (1974). What students think of advertising? Journal of Advertising Research, 14 (1), 33-38.

Hawkins, D.I., \& Coney, K.A. (1976). Advertising and differentiated sex roles in contemporary American society. Journal of the Academy of Marketing Science, 4, 418-28. 
Hofstede, G. (1980). Culture's Consequences: International Differences in Work-related Values. Sage, Beverly Hills, CA.

Hofstede, G. (1991). Culture and Organization: Software of the Mind. Mc Graw-Hill, London.

Hong, J.W., Muderrisoglu, A., \& Zinkhan, G.M. (1987). Cultural differences and advertising expression: a comparative content analysis of Japanese and US magazine advertising. Journal of Advertising, 16 (1), 55-62, 68.

Kluckhohn, F.R., \& Strodbeck, F.L. (1961). Variations in Value Orientations, Row-Peterson. Evanston, IL.

Larkin, E. (1977). A factor analysis of college student attitudes towards advertising. Journal of Advertising, 6 (2), 42-46.

Lutz, R. J. (1985). Affective and cognitive antecedents of attitudes towards the Ad: A conceptual framework in Psychological Process and Advertising Effects: Theory, research and Application.

Mac Kenzie, S.B., \& Lutz, R.C. (1989). An empirical examination of the structural antecedents of attitudes towards the Ad in an Advertising Presenting Content. Journal of Marketing, 53 (4), 48-65.

McCarty, J.A. (1994). The role of cultural value orientations in cross-cultural research and international marketing and advertising, in English, B.G. (Ed.), Global and Multinational Advertising, Lawrence Erlbaum, Hillsdale, NJ, pp. 23-45.

Meth, C. D. (1999). Was it worth? Business Central Europe, 11, 14-19.

Mittal, B. (1994). Public assessment of TV advertising: Faint praise and harsh criticism. Journal of Advertising Research, 34 (1), 35-53.

Munusamy, J., \& Hoo, C. W. (2007). Attitude towards advertising among students at private higher learning institute in selangor. Unitar E-Journal, 3(1), 31-51.

Norris, V. (1984). The economic effects of advertising: A review of the literature. Current Issues and Research in Advertising, 7 (2), 39-134.

O'Donohoe, S. (1995). Attitudes to advertising: A review of British and American Research. International Journal of Advertising, 14 (3), 45-61.

Petrovici, D., \& Marinov, M. (2005). Determinants and antecedents of general attitudes towards advertising: A study of two EU accession countries. European Journal of Marketing, 41(3/4), 2007.

Pollay, R. W. (1986a). The distorted mirror: Reflections on the unintended consequences of advertising. Journal of Marketing, 50, 18-36.

Polly, R., \& Mittal, B. (1993). Here are the beef factors, determinants, and segments in consumer criticism of Advertising. Journal of Advertising, 57 (7), 99-114.

Ramaprasad, J., \& Thurwanger, M.L. (1998). South Asian students attitudes and beliefs about advertising: measuring across cultures. In International Communication Division, AEJMC Annual Conference, Baltimore.

Richins, M. (1991). Social comparison and the idealized images of advertising. Journal of Consumer Research, 18 (6), 71-83.

Rokeach, M. (1973). The Nature of Human Values. The Free Press, New York, NY.

Rossiter, J. R. (1977). Reliability of a short test measuring children's attitudes toward TV commercials. Journal of Consumer Research, pp. 179-184.

Rotzoll, K. B., Haefner, J. E., \& Sandage, C. H. (1986). Advertising in contemporary society. West Chicago, IL: South-Western Publishing Company.

Samovar, L., Porter, R. \& Stefani, L. (1998). Communication between Cultures, Wadsworth Publishing, Belmont, CA.

Sandage, C.H., \& Leckenby, J.D. (1980). Students' Attitudes towards Advertising: Institution vs. Instrument. Journal of Advertising, 9 (2), 29-32.

Schwartz, S.H. (1992). Universals in the content and structure of values: theoretical advances and empirical tests in 20 countries, in Zanna, M. (Ed.), Advances in Experimental Social Psychology, Vol. 25, Academic Press, New York, NY,1-65. 
Shao, T., Raymond, M.A., \& Taylor, C.R. (1999). Shifting advertising appeals in Taiwan. Journal of Advertising Research, 39 (6), 61-9.

Shavitt, S., Lowrey, P., \& Haefner, J.E. (1998). Public attitudes toward advertising: More favourable than you might think. Journal of Advertising Research, 38, (4): 7- 2.

Tai, S.H.C. (1997). Advertising in Asia: localize or regionalize?. International Journal of Advertising, 16 (1), 48-61.

Tan, J. S., \& Chia, L. (2007). Are we measuring the same attitude? Understanding media effects on attitude towards advertising. Marketing Theory, Sage publication. 7(4), 353-373.

Tharp, M., \& Scott, L. M. (1990). The role of marketing processes in creating cultural meaning. Journal of Macro Marketing, 10 (11), 47-60.

Tsang, P.M., \& Tse, S. (2005). A hedonic model for effective web marketing: An empirical examination. Industrial Management and Data Systems, 105 (8), 1039-1052.

Watson, J., Lysonski, S., Gillan, T., \& Raymore, L. (2002). Cultural values and important possessions: a cross-cultural analysis. Journal of Business Research, 55 (11), 923.

Wills, J. R., \& Ryans, J. K. (1982). Attitudes toward advertising: A multinational study. Journal of International Business Studies, 13 (3), 121-29.

Yang, C. C. (2000). Taiwanese students' attitudes and beliefs about advertising. Journal of Marketing Communication, 6, 71-183.

Zanote. (1984). Public advertising towards advertising. International Journal of Marketing, 13, 3-15.

Zhang, Y., \& Gelb, B.D. (1996). Matching advertising appeals to culture: the influence of product use conditions. Journal of Advertising, 25(3), 29-46.

Table 1. ANOVAb

\begin{tabular}{llrrrrr}
\hline \hline Model & & Sum of Squares & df & Mean Square & F & Sig. \\
\hline 1 & Regression & 6.007 & 3 & 2.002 & 12.264 & $.000^{\mathrm{a}}$ \\
& Residual & 40.163 & 246 & .163 & & \\
& Total & 46.170 & 249 & & & \\
& & & & & & \\
\hline \hline
\end{tabular}

a. Predictors: (Constant), Product_Information, Hedonism, Social_Integration

b. Dependent Variable: Atitude

Table 2. Coefficients (a)

\begin{tabular}{|l|l|c|c|c|l|l|}
\hline Model & & \multicolumn{2}{|c|}{$\begin{array}{c}\text { Unstandardized } \\
\text { Coefficients }\end{array}$} & $\begin{array}{c}\text { Standardized } \\
\text { Coefficients }\end{array}$ & \multirow{2}{*}{ Sig. } \\
\hline & & $\mathrm{B}$ & Std. Error & Beta & $\mathrm{t}$ & $\mathrm{S}$ \\
\hline 1 & (Constant) & 2.971 & .171 & & 17.381 & .000 \\
& Product Information & .102 & .049 & .131 & 2.085 & .038 \\
\hline
\end{tabular}

a Dependent Variable: Attitude

Table 3. Coefficients (a)

\begin{tabular}{|c|c|c|c|c|c|c|}
\hline \multirow[t]{2}{*}{ Model } & & \multicolumn{2}{|c|}{$\begin{array}{l}\text { Unstandardized } \\
\text { Coefficients }\end{array}$} & \multirow{2}{*}{$\begin{array}{c}\text { Standardized } \\
\text { Coefficients } \\
\text { Beta } \\
\end{array}$} & \multirow[t]{2}{*}{$\mathrm{t}$} & \multirow[t]{2}{*}{ Sig. } \\
\hline & & B & Std. Error & & & \\
\hline 1 & $\begin{array}{l}\text { (Constant) } \\
\text { Social Integration }\end{array}$ & $\begin{array}{c}2.605 \\
.212\end{array}$ & $\begin{array}{l}.127 \\
.037\end{array}$ & .513 & $\begin{array}{c}20.562 \\
5.778\end{array}$ & $\begin{array}{l}.000 \\
.000\end{array}$ \\
\hline
\end{tabular}

a Dependent Variable: Attitude 
Table 4. Coefficients (a)

\begin{tabular}{|c|c|c|c|c|c|c|}
\hline \multirow[t]{2}{*}{ Model } & & \multicolumn{2}{|c|}{ Unstandardized Coefficients } & \multirow{2}{*}{\begin{tabular}{|l}
$\begin{array}{r}\text { Standardized } \\
\text { Coefficients }\end{array}$ \\
Beta \\
\end{tabular}} & \multirow[t]{2}{*}{$\mathrm{t}$} & \multirow[t]{2}{*}{ Sig } \\
\hline & & B & Std. Error & & & \\
\hline 1 & $\begin{array}{l}\text { (Constant) } \\
\text { Hedonism }\end{array}$ & $\begin{array}{l}2.924 \\
.118\end{array}$ & $\begin{array}{l}.113 \\
.033\end{array}$ & .224 & $\begin{array}{l}25.897 \\
3.628\end{array}$ & $\begin{array}{l}.000 \\
.000\end{array}$ \\
\hline
\end{tabular}

a Dependent Variable: Attitude

Table 5. ANOVA (moderator analysis)(b)

\begin{tabular}{|l|l|r|r|r|c|c|}
\hline \hline Model & & Sum of Squares & \multicolumn{1}{c|}{ df } & Mean Square & F & Sig. \\
\hline 1 & Regression & 2.678 & 2 & 1.339 & 7.605 & $.001(\mathrm{a})$ \\
& Residual & 43.492 & 247 & .176 & & \\
& Total & 46.170 & 249 & & & \\
\hline \hline
\end{tabular}

a Predictors: (Constant), Hedonism, mod2Hedo

b Dependent Variable: Atitude

Table 6. ANOVA (moderator analysis)(b)

\begin{tabular}{|l|l|r|r|r|r|c|}
\hline \hline Model & & Sum of Squares & \multicolumn{1}{c|}{$\mathrm{df}$} & Mean Square & F & Sig. \\
\hline 1 & Regression & 1.115 & 2 & .557 & 3.056 & $.049(\mathrm{a})$ \\
& Residual & 45.056 & 247 & .182 & & \\
& Total & 46.170 & 249 & & & \\
\hline \hline
\end{tabular}

a Predictors: (Constant), Product_Information, mod3PI

b Dependent Variable: Atitude

Table 7. ANOVA (moderator analysis) (b)

\begin{tabular}{|l|l|r|r|r|r|c|}
\hline \hline Model & & Sum of Squares & \multicolumn{1}{c|}{ df } & Mean Square & F & Sig. \\
\hline 1 & Regression & 5.826 & 2 & 2.913 & 17.836 & $.000(\mathrm{a})$ \\
& Residual & 40.344 & 247 & .163 & & \\
& Total & 46.170 & 249 & & & \\
\hline \hline
\end{tabular}

a Predictors: (Constant), Social_Integration, mod1SI

b Dependent Variable: Atitude 
Table 8. Correlations

\begin{tabular}{|c|c|c|c|c|c|c|}
\hline & & $\begin{array}{l}\text { Product_- } \\
\text { Information }\end{array}$ & Atitude & $\begin{array}{c}\text { Social_- } \\
\text { Integration }\end{array}$ & Hedonism & Culture \\
\hline \multirow[t]{3}{*}{ Product_Information } & Pearson Correlation & 1 & $.131^{*}$ & $.147^{*}$ & .114 & $.141^{*}$ \\
\hline & Sig. (2-tailed) & & .038 & .020 & .072 & .026 \\
\hline & $\mathrm{N}$ & 250 & 250 & 250 & 250 & 250 \\
\hline \multirow[t]{3}{*}{ Atitude } & Pearson Correlation & $.131^{*}$ & 1 & $.344 * 1$ & $.224 * y$ & -.070 \\
\hline & Sig. (2-tailed) & .038 & & .000 & .000 & .269 \\
\hline & $\mathrm{N}$ & 250 & 250 & 250 & 250 & 250 \\
\hline \multirow[t]{3}{*}{ Social_Integration } & Pearson Correlation & $.147 *$ & $.344^{* *}$ & 1 & $.462 * *$ & -.022 \\
\hline & Sig. (2-tailed) & .020 & .000 & & .000 & .734 \\
\hline & $\mathrm{N}$ & 250 & 250 & 250 & 250 & 250 \\
\hline \multirow[t]{3}{*}{ Hedonism } & Pearson Correlation & .114 & $.224 * *$ & $.462 * 1$ & 1 & -.010 \\
\hline & Sig. (2-tailed) & .072 & .000 & .000 & & .879 \\
\hline & $\mathrm{N}$ & 250 & 250 & 250 & 250 & 250 \\
\hline \multirow[t]{3}{*}{ Culture } & Pearson Correlation & $.141 *$ & -.070 & -.022 & -.010 & 1 \\
\hline & Sig. (2-tailed) & .026 & .269 & .734 & .879 & \\
\hline & $\mathrm{N}$ & 250 & 250 & 250 & 250 & 250 \\
\hline
\end{tabular}

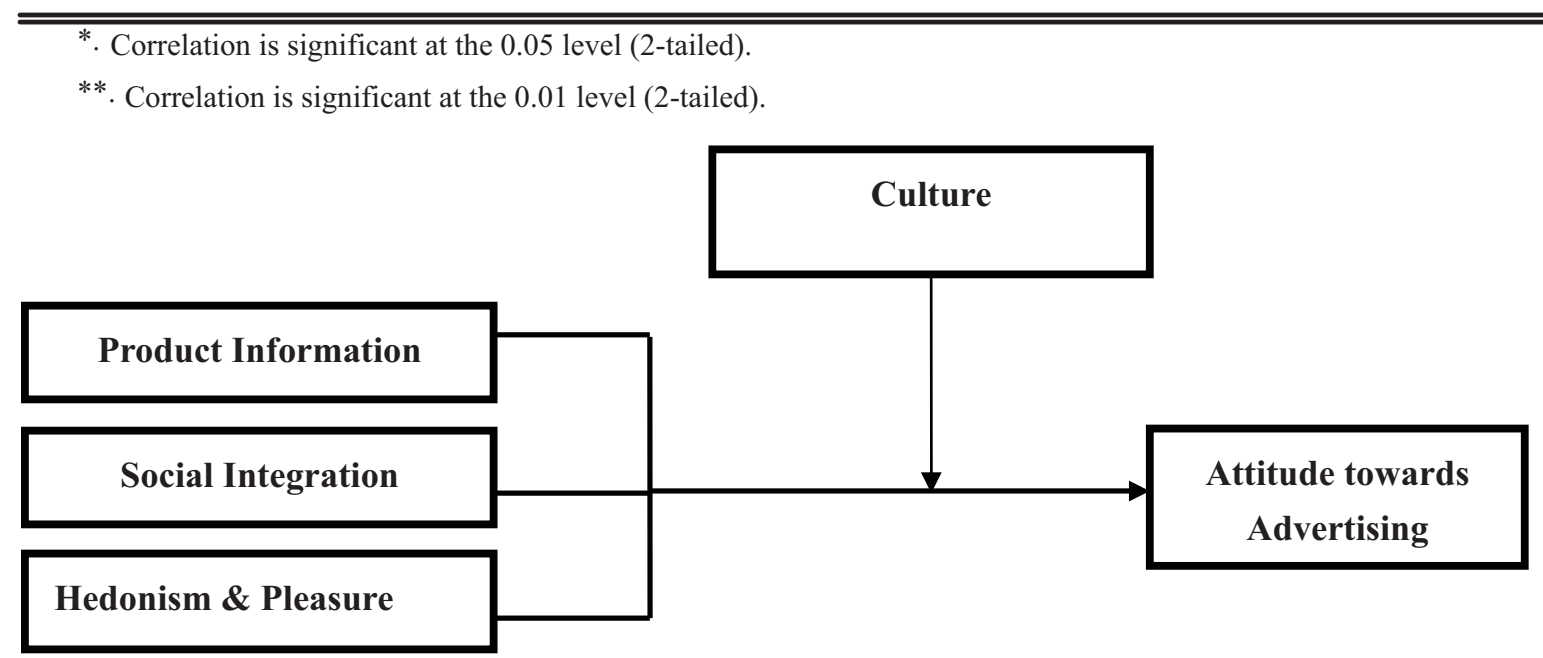

Figure 1. Theoretical Framework 